\title{
REFLEXÕES SOBRE A INFLUÊNCIA DE MAQUIAVEL NA EDUCAÇÃO E NA FORMAC̣ÃO DO ESTADO MODERNO
}

\author{
Terezinha Oliveira* \\ Sandra Regina Franchi Rubim**
}

RESUMO: Este texto tem como objetivo analisar algumas formulações de Nicolau Maquiavel sobre a teoria política, bem como refletir sobre a contribuição de suas ideias, expostas na obra O Príncipe, para a formação do Estado Moderno Absoluto. Essa obra foi resultado de suas reflexões sobre os problemas do seu tempo: séculos XV e XVI, na Itália. O Príncipe expressava o desenvolvimento dos Estados Nacionais, a dessacralização do político, a independência do poder temporal em relação ao poder religioso e a primazia do Estado frente à religião. Consideramos que a obra de Maquiavel é de suma relevância para a história das ideias, principalmente, no campo da ciência política. Dessa forma, destacamos a importância do estudo de seu pensamento sob a perspectiva da Educação, o qual nos possibilita a compreensão dos fundamentos políticos da modernidade e, por conseguinte, o entendimento da formação do homem político-moderno.

Palavras-chave: História da Educação. Governante. Estado Moderno.

\section{REFLECTIONS ON MACHIAVELLI'S INFLUENCE IN EDUCATION AND IN THE FORMATION OF THE MODERN STATE}

ABSTRACT: This work aims to analyze some of Nicolas Machiavelli's formulations on political theory, as well as to reflect on the contribution of his ideas to the formation of the Absolute Modern State, in his work The Prince. The Prince was the result of his reflections on the problems of his time: the fifteenth and sixteenth centuries in Italy. His work expressed the development of Nation States, the removal of the sacred dimension from the political one, the independence of temporal power from religious power and the primacy of the state over religion. Machiavelli's work is considered to be highly important for the history of ideas, especially in the field of political science. Therefore, the importance of studying his thinking within an educational perspective is highlighted, enabling us to understand these political principles, so formative of modern society, and hence, understand the formation of the modern political man.

Keywords: History of Education. Ruler. Modern State.

\footnotetext{
* Pós-Doutora em Filosofia da Educação pela Universidade de São Paulo (USP) e Professora do Departamento de Fundamentos da Educação e do Programa de Pós-Graduação em Educação da Universidade Estadual de Maringá (UEM). E-mail: teleoliv@gmail.com

* * Mestre em Educação pelo Programa de Pós-Graduação em Educação da Universidade Estadual de Maringá (UEM). E-mail: srfrubim@gmail.com
} 


\section{Introdução}

É perceptível, na contemporaneidade, a permanência da atividade política e o fortalecimento do Estado, tornando premente analisar o sentido da política, sua natureza, seus objetivos, suas finalidades e exigências e suas limitações. Em face disso, analisar as formulações de Maquiavel (1469-1527) é importante, pois podemos dizer que, em se tratando de reflexões sobre a política, sua tese é ainda muito atual. De acordo com Bath (1981), ele foi o primeiro a dedicar sua capacidade intelectiva na prática política do passado e do seu tempo histórico, trazendo à tona e definindo a real atividade política, diferente da debatida, até então, pelos teóricos e utopistas do seu tempo.

Hoje, procura-se verificar a contribuição específica que Maquiavel propiciou à história das ideias, especialmente aquelas concernentes à ciência política. Segundo Bignotto (2007, p. 53), Maquiavel “[...] teria transformado o panorama da filosofia política do Ocidente, descobrindo novos objetos, novos métodos, novos interesses. De sua paixão pela política nasceu uma nova compreensão da vida em comum dos homens". Podemos assinalar, portanto, que a revolução nos estudos políticos deu-se na Itália, no início do século XVI, com Maquiavel. Ao defender a unidade italiana, esse intelectual propôs a construção de um Estado laico, independente da Igreja e dirigido, de modo absoluto, por um príncipe dotado de inteligência e de inflexibilidade na direção dos negócios públicos.

Analisaremos o pensamento inovador de Maquiavel, no limiar do Renascimento italiano, que percebe o Estado como um fato social, ou seja, considera a história e a sociedade como fenômenos humanos e naturais, distanciando-se de julgamentos ou de condenações religiosas e morais. Maquiavel declara que o saber político assenta em um entendimento adequado do passado. Ele recorreu a seus conhecimentos da história antiga para refletir as temáticas centrais de sua tese política. Para ele, o passado nos serve de exemplo, nos possibilitando prever o futuro, fazendo uso das soluções aplicadas em outros tempos ou, na ausência deles, criar novos, em consonância com a similaridade de circunstâncias entre o passado e o presente. No capítulo VI de sua obra O Principe, assinala ser prudente imitar os grandes homens que se destacaram por sua excelência. E, assim, aquele que os imitarem deve agir 
[...] como os arqueiros prudentes que, quando desejam acertar uma posição muito distante, conhecendo o alcance da sua seta, alvejam um ponto muito mais elevado, não para atingi-lo, mas para alcançar a posição que pretendem de fato ferir, por meio dessa mira elevada (MAQUIAVEL, 1979, p. 54).

Esse excerto nos permite entender que, para Maquiavel, ensinar aos homens a prudência é de suma relevância. Podemos dizer que até para solucionar as coisas pequenas precisamos ter atitudes grandes. O florentino compartilhava da confiança dos humanistas, em geral, no valor do estudo do passado, enquanto guia para a vida moderna. Ao conhecer a História aprendemos com o comportamento dos homens, podendo, assim, ter a possibilidade de não cometer os mesmos erros. É necessário olharmos para a História com a posição de partícipes do processo de construção do conhecimento, nos conscientizando da história e de nosso lugar no mundo. Faz-se necessário, portanto, conhecermos as formulações de Maquiavel como exemplos para que, no presente, nos posicionemos com autonomia intelectual diante dos problemas cotidianos.

Assim, partindo da premissa de que o processo educativo ocorre no seio das relações humanas, o princípio da História da Educação é construir fundamentos para a educação, por meio dos caminhos da História. Torna-se relevante compreender como o pensamento de autores clássicos, como Maquiavel, influenciou as ideias de educação, de conhecimento, de cultura, no início do século XVI.

Examinaremos, pois, em O Príncipe (1513), a contribuição do pensamento de Maquiavel, no seu tempo e em sua ambiência, para o desenvolvimento do ser humano e da sociedade, bem como a sua importância para a contemporaneidade, vista como subsídio para abordarmos as questões atuais com mais propriedade. Frisamos, também, que este estudo pode orientar o pesquisador da área de Educação na abordagem da formação do homem moderno, em face da nova organização social que se configurava.

\section{A importância do estudo de Maquiavel na contemporaneidade}

Assistimos, hoje, à expansão e à consolidação de estudos dos clássicos, focados na compreensão da sociedade, dos homens e do processo educativo. Constatamos a relevância de olharmos para o passado, 
querer e reconhecer, nas primeiras civilizações, as nossas raízes. É inquestionável o entendimento de que somos história, partimos de algo e que, portanto, esse algo precisa ser conhecido. Como questionou Duby (1999, p. 9), "[...] Para que escrever a história se não for para ajudar seus contemporâneos a ter confiança em seu futuro e a abordar com mais recursos as dificuldades que eles encontram cotidianamente?" Consideramos que a História se apresenta como fonte de conhecimento e exemplo de ações dos homens em outros tempos. Percebe-se, assim, a possibilidade de aprendermos com as experiências do outro, acumular vivências que nos munem e nos capacitem no presente. Não como imitação, mas, sim, vistas como subsídios para abordarmos as questões atuais com mais discernimento.

Assim, reconhecemos o caráter educativo da História no que concerne à formação do homem contemporâneo na sua totalidade, porque ela nos dá um leque de possibilidades que amplia o nosso olhar para a realidade. Dessa forma, destacamos a importância da leitura dos clássicos, como Maquiavel, foco de nossas reflexões. Os clássicos, segundo Calvino (1993), se constituem como os grandes escritos de formação, que transcendem o aspecto de informação, que transmitem ensinamentos preciosos. Deles emanam conhecimentos para qualquer momento da existência humana. As ideias de diferentes autores, de épocas distintas, resistiram ao tempo na medida em que trataram da essência constitutiva do homem.

Ainda, sob essa perspectiva da história, relembremos a afirmativa de Bloch (1965) de que há um fundo permanente de reserva de conhecimento que a auxilia a vida no presente.

Já não pensamos hoje, realmente, como o escrevia Maquiavel, como o pensava Hume ou Bonald, que há no tempo "uma coisa, pelo menos, que é imutável: o homem". Aprendemos que também o homem mudou muito: no seu espírito e, provavelmente, até nos mais delicados mecanismos do corpo. Como poderia ser de outro modo? Transformou-se profundamente a sua atmosfera mental; e também a sua higiene, sua alimentação. Convimos, todavia, em que existe na natureza humana e nas sociedades humanas um fundo permanente. Se assim não fosse, os próprios vocábulos de "homem" e de "sociedade" não significariam coisa nenhuma (BLOCH, 1965, p. 42).

Nesse excerto, o autor se refere aos fundamentos de nossa humanidade, da similaridade de nossos receios, de nossos desejos, nossas imprecisões, nossas indagações. Os clássicos nos dão acessibilidade a 
exemplos, como já mencionamos, de como os homens viveram, educaram, enfrentaram as vicissitudes cotidianas.

Com efeito, estudar a história de várias gerações é estudar nossas próprias ideias e ver como chegamos a adquiri-las. Ao compreendermos como os grandes filósofos, como Tomás de Aquino (1225-1274), Maquiavel, Montesquieu (1689-1755), Guizot (1787-1874) e outros trataram seus problemas, buscando pelo pensamento a melhor maneira de ordenar as relações humanas, poderemos, então, pensar nossa sociedade e intervir nela. Torna-se relevante compreender como o pensamento dessas autoridades influenciou a construção do conceito de educação, de conhecimento, de cultura.

Importa, pois, pelo viés dos clássicos, em especial Maquiavel, nos apropriarmos de seu legado como homem que foi capaz de olhar para além de si, percebendo qual poderia ser sua contribuição para o seu momento, o seu tempo, ou seja, ver sua Itália unificada e forte. De acordo com Bignotto (2007), humanistas como Coluccio Salutati (1331-1406), Matteo Palmieri (1406-1475), Leon Battista Alberti (1404-1472), Maquiavel, influenciados por Petrarca (1304-1374), descobriram o quanto era valioso refletir sobre a organização das cidades, suas constituições e suas construções como matérias nobres.

\section{Tempo histórico e ambiência de Maquiavel}

O estudo em tela será desenvolvido no sentido de vincular a filosofia política do autor com o momento histórico em que ele viveu, dentro do quadro de sua vida pessoal e das condições sociais da Europa dos séculos XV e XVI, em especial, a situação das cidades-estados italianas.

De acordo com Masters (1999), foi em meio à invasão da Itália ${ }^{1}$ que Maquiavel desempenhou, durante 14 anos, a função de Segundo Secretário da Chancelaria de Florença (1498-1512), eleito pelo Conselho dos Oitenta ${ }^{2}$, órgão maior da estrutura de governo da cidade. Tornou-se uma figura importante no cenário político.

Esses cargos propiciaram a Maquiavel um extenso conhecimento da política, conscientizando-o da complexidade dos acontecimentos correntes e das deficiências do governo florentino. Suas viagens permitiram-lhe, sem dúvida, se distanciar da Itália e com isso ver melhor os seus 
problemas. Teve oportunidades de observar ações de papas, reis e líderes militares, aprendendo, assim, a respeito da sutileza política e do uso da força. Pode visualizar a Itália de fora, presenciar as lutas partidárias da península na esfera política internacional, avaliar todas as forças envolvidas que remodelavam os destinos dos Estados Italianos. Sua obra literária fora marcada tanto por precedentes clássicos quanto pela experiência moderna. Afirmamos que o envolvimento de Maquiavel em assuntos políticos, diplomáticos e militares foi decisivo para a formação de seu pensamento. Como secretário, Maquiavel usufruía de grande confiança do gonfaloneiro, cargo vitalício da república, Piero Soderini (1498-1512). No entanto, em 31 de agosto de 1512, quando exércitos espanhóis derrotaram a república, Soderini se rendeu para evitar os saques. Os partidários dos Medici se apoderam dos postos-chave da administração. Em 16 de setembro, destituiu-se o governo republicano. Nesse cenário, Maquiavel foi deposto de suas funções e ficou sem o cargo e impedido de se envolver em ações políticas. No início, acalentava esperanças de ser útil ao novo governo, pois fora um funcionário fiel e competente. Todavia, em 19 de fevereiro de 1513, seu sonho evanesceu, sendo aprisionado e torturado como um conspirador contra os Medici'. Refugiou-se em sua propriedade de Saint'Andrea, valendo-se de sua formação como poeta e literato. Nesse período, escreveu suas obras mais importantes: O Principe (1513); os Comentários (1515-17); A Arte da Guerra (1519-20) e A História de Florença (1520/25). Maquiavel morreu em 1527, ano em que Roma foi saqueada pelas forças do imperador Carlos V (1500-1558), do Sacro Império Germânico (BIGNOTTTO, 2007).

Nesse contexto de crise, os florentinos, entre eles Maquiavel, se encontravam unidos por uma preocupação comum: o receio de perderem a independência. A perda de Pisa, em 1494, local de suma importância para a atividade comercial de Florença, foi um golpe para os florentinos, levando-os a não mais recobrarem sua autoconfiança. Ameaçados por guerras e outros perigos, difundiu-se a ideia em favor de um governo personificado em uma única família e, depois, em um só homem: o príncipe.

Maquiavel, aos 27 anos, viu Florença iniciar sua longa, dispendiosa e apaixonada luta pela reconquista de Pisa. Os interesses florentinos, após a saída dos franceses, se dividiam entre a guerra com Pisa e o declínio do poder de Savonarola. Ele escreveu O Príncipe em momentos em que Florença alternava entre a forma de administração republicana ou a prin- 
cipesca. Via de forma prática o projeto de todas as personalidades e grupos. A França e a Espanha passaram a ser vistas como inimigas impiedosas, com recursos humanos e financeiros significativos, em constantes guerras para dominar as províncias italianas, como Milão, Veneza, Florença, Nápoles. Havia um jogo de poder entre as Dinastias Valois e Habsburgo. Os Estados, na Itália, viviam uma inconstância. Internamente, nesses Estados, ocorriam inúmeras crises, algumas superadas e outras se convertiam em revoluções. O perigo era iminente: a ambição de Veneza, os papas dispostos a fazer uso de armas para restabelecer a glória e a segurança temporais da Igreja, o crescente poderio dos suíços, a curta experiência de César Bórgia que reuniu várias senhorias semi-independentes em uma província administrativa centralizada em Romagna, criou um quadro de profunda crise política e social (HALE, 1963).

Assim, O Príncipe constitui uma tentativa de restituir, aos florentinos e ao seu governo, o sentimento de autodeterminação. Maquiavel parte do desejo e da possibilidade de ver a Itália unida e forte. A teoria de Maquiavel sobre a decadência dos Estados e a passagem da República à monarquia advém da observação atenta da história, sobre a forma como os Estados se formam, decaem e ressurgem. Sua preferência é pela república, pois acredita que o principado é mais fraco, no entanto, Maquiavel reflete sobre as distintas formas de organização política, sobre a fisionomia específica de cada uma, sem definir sobre qual forma de governo seria superior.

\section{Príncipe de Nicolau Maquiavel e sua contribuição para a formação do Absolutismo}

$\mathrm{Na}$ sociedade italiana de fins do século XV e início do XVI, marcada pela fome generalizada, pelas doenças endêmicas, pelas guerras permanentes, a figura de um monarca que pudesse trazer a unidade política e a paz tornou-se parte do imaginário político da população e dos políticos de modo geral. No momento em que um conjunto de mudanças sociais caracterizava o alvorecer do mundo moderno, a crença de que o absolutismo e o direito dos monarcas para governar eram divinos tornou-se, na teoria e na prática, uma possibilidade de assegurar a paz e a ordem social. A atribuição de um poder ilimitado ao Estado, embora não fosse exata- 
mente inédita, era uma ideia nova, no sentido de ser aceita sem maior controle institucional e sem perda de sua legitimidade.

Saldanha (1987) indica que o Estado, em sua tendência unificadora, toma as rédeas da atividade econômica, fundindo a política e a economia no sistema mercantilista. Expandindo-se em direção às terras descobertas no além mar, o recém-Estado absolutista, dinamizou a economia dos países europeus sob os mais amplos aspectos. À concentração do poder monárquico pode-se acrescentar o aparecimento de uma justiça do rei. O direito foi unificado na medida em que surgiam cortes de justiça diretamente ligadas ao poder real, em que se reformulavam competências, sistematizando-se o processo judicial. Do conjunto de costumes elaborados desde o início da Idade Média sob a forma do direito consuetudinário, a justiça tornou-se, gradativamente, um direito escrito resultante de um trabalho meticuloso dos funcionários da corte sob o jugo do monarca. O surgimento dessa nova estrutura política implicou uma série de mudanças em termos de valores, relações, modos de vida, padrões de atitudes, usos, símbolos, crenças e posições. Nesse contexto, o princípio de legitimidade do rei sofreu algumas alterações. É verdade que ainda persistiu a ideia de legitimidade do monarca pela linhagem, mas novos elementos entravam em cena: a noção de soberania do rei, do Estado e a concepção de um poder soberano incontrariável. O debate em torno da legitimação dessa nova forma de poder do governante inquietou e estimulou o pensamento político nesse momento histórico. Era preciso explicar e, sobretudo, justificar a presença de uma ordem política de âmbito nacional, bem como a existência de um soberano: o monarca. Os grandes pensadores políticos ligados ao ideário absolutista têm todos, cada um em seu contexto e com expressões distintas, relação com o desenvolvimento do conhecimento racional e da secularização absoluta do poder.

$\mathrm{Na}$ chamada Renascença tardia (por volta de fins do século XV e inícios do século XVI), tornava-se mais presente o poder absoluto. Dedicava-se maior atenção ao estudo da política dirigida ao príncipe. Os textos elegiam o príncipe como alvo, mesmo quando estava evidente que suas preferências pessoais pendiam para a República. A preocupação desses autores fez com que ficasse centralizada a atenção na figura mais poderosa do príncipe, em detrimento da consideração do cidadão individual (SKINNER, 1996). 
Uma possível explicação para esse tratamento dado ao poder centralizado relaciona-se ao fato de que os elementos necessários para estabelecer uma república tinham desaparecido. Como argumenta Burckhardt (1973, p. 55), “[...] certamente, no seu foro íntimo, todos protestavam contra o poder de um só, mas procuravam mais acomodar-se ao regime ou até a beneficiar dele do que a reunir-se a outros para o atacar". Nesses termos, podemos destacar que Maquiavel, com sua perspicácia, soube perceber o elo que se organizou entre a cultura literária e a vida política, e os problemas de Florença nortearam suas reflexões.

No início do século XVI, a Itália, com Maquiavel, foi palco de grandes mudanças nos estudos políticos. O autor foi homem de ação, capaz de pensar a política com realismo. Apesar de sua predileção pela república em sua cidade de Florença, desolada pela impetuosidade dos Medici, desenvolveu sua teoria sobre o principado (BIGNOTTO, 1991). Ao defender a unidade italiana, esse intelectual pregou a construção de um Estado laico, dirigido por um príncipe único, dotado de inteligência e inflexível na direção dos negócios públicos. $\mathrm{Na}$ esfera dos atos humanos, ele atribuiu à conquista um lugar importante no movimento que constitui a política. Em O Príncipe, Maquiavel (1979, p. 51) afirma que: "O desejo de conquista é algo natural e comum; aqueles que obtêm êxito na conquista são sempre louvados, [...]". Há, pois, a possibilidade de certas ações recriarem as condições imperiosas para o aparecimento de sociedades fortes. Lembremos que Maquiavel escrevia para uma geração que, tendo assistido à derrota da República Florentina, passara a acreditar mais na força como elemento constitutivo da política. Em Maquiavel percebemos, assim, o rompimento do pensamento de modelo ideal de política. Nele abre-se espaço para a crítica do regime ideal. Sua atenção volta-se ao estudo da regulação das relações do indivíduo com o Estado, bem como desvendar com objetividade aos leitores a origem das leis e a inevitável ruptura do corpo social (BIGNOTTO, 1991).

Salientamos que, no contexto de crise do século XVI, todos os florentinos, entre eles Maquiavel, encontravam-se unidos por uma preocupação comum: o receio de perder sua tão estimada independência. $\mathrm{O}$ monarca, por seu turno, seria o único capaz de governar a sociedade; de assegurar a paz, a justiça, condições indispensáveis para o desenvolvimento do indivíduo e do intelecto. Ao Estado atribui-se a função de se opor, pela força das leis, à ação avassaladora das aspirações pessoais; sua postu- 
ra não é de mediador neutro e nem de juiz impessoal. Os homens são incapazes de atos espontâneos de cooperação para a constituição da sociedade política.

Nesse sentido, segundo Ames (2002), Maquiavel elabora uma teoria do desejo que leva os homens a agirem mediante determinadas conjunturas. O homem é insaciável, é um ser carregado de desejo, inclinado ao egoísmo. Saltam de uma ambição para a outra, como riquezas, honra, posses, poder político, segurança. Não há ação humana sem interesse. Ele considera que a ambição não é nem boa e nem má. O príncipe prudente deve refrear sua natureza humana e a de seus súditos, pois "[...] os bons exemplos nascem da boa educação; a boa educação, das boas leis [...]" (MAQUIAVEL, 2007, p. 22). Essa mesma questão do exemplo do príncipe como elemento educativo é retomada no Príncipe quando ao autor diz que a Fortuna "[...] decide a metade dos nossos atos, mas que nos permite o controle sobre a outra metade [...]" (MAQUIAVEL, 1979, p. 90). Depreende-se das reflexões de Maquiavel que ele concebe o homem como agente de seus atos, portanto capaz de escolher seu caminho, pelo fato de possuir livre arbítrio, mas precisa de um direcionamento que o ajude a fazer as escolhas corretas. Esse direcionamento pode ser realizado por meio do exemplo do governante, pela educação e de boas leis.

Segundo Gramsci (1991), nessas condições, O Príncipe de Maquiavel apresentava a possibilidade de um governante atuar sobre um povo sem unidade, despertando e organizando sua vontade coletiva. $\mathrm{O}$ condottiero representava a vontade coletiva na direção de um fim político determinado. Consideremos suas palavras:

O caráter utópico do Príncipe consiste em que o Príncipe não existia na realidade histórica, não se apresentava ao povo italiano com características do imediatismo objetivo, mas era uma pura abstração doutrinária, o símbolo do chefe, do condottiero ideal; [...] este é convocado para vir existir. [...] Em todo o livro Maquiavel mostra como deve ser o Príncipe para levar um povo à fundação do novo Estado, e o desenvolvimento é conduzido com rigor lógico, com relevo científico; [...] (GRAMSCI, 1991, p. 4).

De acordo com o autor, o moderno príncipe deveria ser o divulgador e o patrocinador de uma reforma intelectual, moral e econômica que possibilitasse o desenvolvimento dessa vontade de fundar um novo Estado. O governante deveria ser a expressão ativa e atuante desse obje- 
tivo, bem como, o idealizador e dirigente das relações tecidas nesse Estado único.

Maquiavel concebeu $O$ Príncipe (1513) nos parâmetros de um gênero literário chamado espelho dos príncipes ${ }^{4}$, que continuava a ser usado no início do século XVI. Os temas escolhidos por Maquiavel em relação às virtudes principescas e à conservação de seu reino são os mesmos. No entanto, as respostas dadas por ele diferem das dos que o precederam, neste gênero. $\mathrm{O}$ novo príncipe era aliado do perigo, de riscos. $\mathrm{Na}$ Florença, que há muito tempo deixara de ser uma república e que vivia somente de aparências, exigia-se uma escrita política peculiar. Assim, Maquiavel fez uma associação entre o movimento de seu discurso, que contrariava muitos de seu tempo, ao conhecimento da época e ao público ao qual a obra se destinava (BIGNOTTO, 2007).

Segundo Maquiavel, a obra ${ }^{5}$ era resultado de sua própria apreciação da estratégia e da tática, do estudo meticuloso e do registro preciso tanto da ação política do passado quanto da contemporânea. Ao estabelecer regras de comportamento para o governante, instruindo-o na arte de conquistar o poder e de conservá-lo, O Príncipe tornou-se um instrumento educativo para a formação do monarca e um modelo para a sociedade.

Enfatizamos a ideia de que a obra constitui-se em modelo educativo para a sociedade não porque Maquiavel explicitasse esse objetivo de educar o povo, mas porque, ao evidenciar o modelo de príncipe, ele estaria encaminhamento um projeto para a sociedade, posto que a figura do governante absolutista fosse o modelo e o exemplo para seus súditos.

As reflexões de Maquiavel em O Príncipe, como um instrumento de formação do homem moderno, não se reduziam à transmissão de uma ideia, mas tinham a função de construir uma interpretação de acontecimento, ou seja, ele contrariou a política da Idade Média, trazendo uma nova maneira de entendê-la e uma formação de Estado que não se centrava em ideias, mas, sim, em um Estado possível de ser realizado. Podemos afirmar que o olhar dos que são conquistados é guiado, em primeiro lugar, pelo simples desejo de mudança, que não precisa identificar seu objeto para existir. Com o correr dos acontecimentos, o desejo de mudança se incorpora em algo tangível: o poder do príncipe. Uma vez iniciado o processo de inovação, um combate entre duas posições, o agente de poder e o povo, se instala e dele dependerá o sucesso ou não da empreitada do conquistador. Desse modo, concomitantemente, era preci- 
so projetar a intencionalidade daquele que fazia o discurso, ou seja, legitimar o poder do governante. Os homens deveriam estar convictos de que a autoridade do governante único era indispensável para assegurar a segurança individual e coletiva. O Estado, por meio de seu dirigente modelar, teria a função de ensinar o indivíduo a atuar na sociedade de forma que possibilitasse que os súditos conseguissem aliar seus interesses privados e singulares com os da comunidade/Estado.

É, pois, sob esse aspecto que percebemos em O Príncipe características educativas. Salientamos que o que destacamos como conteúdo educativo não se vincula à ideia de educação formal, mas diz respeito a um princípio de sentimento de pertença que pode ser identificado em uma educação social que permite a construção de identidades políticas nacionais, em consonância ao governante absolutista. $\mathrm{O}$ autor via na figura do governante a possibilidade de ordenar a sociedade, objetivando um governo que buscasse a unificação da Itália e capaz de dar a ela um sentido de público.

Maquiavel, no limiar do Renascimento italiano, percebeu o Estado como um fato social, ou seja, considerou a história e a sociedade como fenômenos humanos e que as relações humanas são modificadas de acordo com as relações sociais de cada tempo histórico. Essa percepção foi possível a Maquiavel em virtude de seu conhecimento da história, e é sob esse aspecto que ele se torna, para nós, um exemplo da história. Ao tê-lo como nesse sentido, afiançamos que o conhecimento de diferentes realidades pode levar o homem a atos intencionais que pressupõem boas escolhas. Segundo o autor, a sabedoria política assenta-se em um entendimento adequado do passado.

De acordo com Maquiavel, o príncipe deveria ter como modelo um personagem histórico que tivesse sido alvo de glória e honra. Ao seguir o modelo de um príncipe do passado, o governante atual poderia saber como manter a submissão daqueles que colaboraram para a sua ascensão e, ao mesmo tempo, diminuir o apetite destes pelo poder. Deveria acabar com a oposição, submeter os conquistados à sua autoridade, defender seu território de ataques estrangeiros e ser capaz de governar na condição que fosse exigida. O governante não poderia fazer algo pautado no voluntarismo porque julgasse ser certo, justo e racional, mas, sim, na concepção da unidade do Estado e no que seria o mais racional e necessário aos seus súditos. Em suma, o príncipe precisaria ser a 
expressão da prudência e do equilíbrio. O florentino assinalava ser importante imitar os grandes homens que se destacaram por sua excelência, porque seus exemplos de combates e glórias contribuíram para o desenvolvimento do poder no seu tempo e com isso possibilitaria o desenvolvimento da sociedade:

Caminham os homens, em geral, por estradas já trilhadas. Aquele que é prudente, desse modo, deve escolher os caminhos já percorridos pelos grandes homens, e copiá-los; sempre muito é aproveitado, ainda que não se possa seguir fielmente esse caminho, nem alcançar inteiramente, pela imitação [...] (MAQUIAVEL, 1998, p. 55).

Para o autor, quem é capaz de observar, com diligência, os fatos do passado, poderá adquirir uma percepção daquilo que convém seguir e daquilo que deve ser evitado. Seu conceito de imitação se constitui como um conhecimento prático, uma lição extraída do passado, que, mantidas as devidas proporções, permite ao homem do poder aplicar com sensatez, no presente ou no futuro, medidas adequadas que permitam um controle mais efetivo da ordem política. Do ponto de vista da intencionalidade, a relação entre o conhecimento da situação concreta e a atitude realizada aponta, para o governante, a necessidade do conhecimento anterior para as escolhas corretas no âmbito da ação. O governante, como legislador único, deverá dedicar-se à manutenção do poder e à conservação do Estado, possibilitando, assim, o desenvolvimento do homem e da sociedade.

Ao abordar a política de forma realista e confrontar com o conhecimento que tinha dela por meio do testemunho da história, Maquiavel direcionava a conduta política em um mundo real. O cerne de seu interesse não foi estudar o modelo ideal de Estado, mas o fenômeno do poder, formalizado na instituição do Estado, buscando compreender como as organizações políticas se fundam, se desenvolvem, perseveram e decaem, especialmente, por meio de seu (s) governante (s).

Como Maquiavel estava envolvido com o poder de sua região, pensa e constrói seu discurso no sentido de consolidar o poder do príncipe e com ele o poder dos Medici que poderiam granjear a posição de líderes da própria Itália. 
[...] far-se-ia necessário que a Itália chegasse aonde se acha neste momento. Que se visse mais escravizada do que os hebreus, mais oprimida do que os persas, mais desunida do que os atenienses, sem chefe, sem ordem, batida, espoliada, lacerada, invadida, e que houvesse, por fim, suportado toda sorte de calamidades. [...] (MAQUIAVEL, 1998, p. 147).

Verifica-se que roga ela a Deus o envio de alguém para redimi-la das crueldades e insolências dos estrangeiros. Nota-se, igualmente, que está pronta e disposta a seguir uma bandeira, desde que haja quem a levante. [...] (MAQUIAVEL, 1998, p. 148).

Caso vossa ilustre casa deseje seguir o exemplo daqueles grandes homens redimir suas províncias, mister se faz, por primeiro, como verdadeiro alicerce de qualquer empresa, prover-se de tropas próprias, uma vez que não há outras mais leais nem melhores.E, não obstante cada soldado possa ser bom, todos reunidos serão ainda melhores quando forem comandados pelo seu príncipe, e por ele honrados e bem tratados. (MAQUIAVEL, 1998, p. 149-150).

[...] Tome, portanto, a vossa ilustre casa tal tarefa, com aquele ânimo e com aquela fé com que se esposam as boas causas, afim de que, sob o seu brasão, seja essa pátria enobrecida [...] (MAQUIAVEL, 1998, p. 151).

$\mathrm{O}$ apoio que Maquiavel forneceu aos Medici estava vinculado a um projeto maior, que era o de unificar a Itália e esta família, a seu ver, reunia condições para efetivar essa unificação porque poderia promover a estabilidade política e vencer seus conquistadores.

De acordo com Skinner (1996), Maquiavel, ao buscar inspiração nas ações e nos valores definidos pelos humanistas do alvorecer do século $\mathrm{XV}$, discorre como um príncipe deve agir para conquistar a honra. $\mathrm{O}$ seu herói ainda é o vir virtutis, ou seja, o homem verdadeiramente viril. Este seria capaz de alcançar o nível de excelência, por meio de uma esmerada educação, proporcionada pelo olhar ao passado, para o legado que os homens tinham construído.

Para ele, segundo Bignotto (2007), assim como para os teóricos dos espelhos dos príncipes, a ação política é um confronto entre a virtú (o empenho) e a fortuna (o acaso). A deusa romana Fortuna seria responsável pela ruína dos mais bem-elaborados de nossos planos, porém ressalta que é possível cortejá-la, e o homem de legítima virtus pode até subjugála, atraindo dela favores. Ele admite que a fortuna possa levar o homem a adquirir um estado, um reino, homens para governar, assim como pela prática da virtú: "Os principados ou são hereditários, e têm como um senhor um príncipe pelo sangue, por longa data, ou são novos. [...] domínios assim [...] adquiridos com tropas alheias ou próprias, pela fortuna ou 
pelo mérito" (MAQUIAVEL, 1998, p. 37). No capítulo VII, cita o exemplo de César Borgia ${ }^{6}$ (1475-1507), que conquistou o poder em decorrência da influência do pai, o papa Alexandre VI (1492-1503). Todavia, o perdeu quando este lhe faltou, ainda que tivesse sido prudente e capaz, o autor o apresenta como modelo a ser imitado, pois César Borgia soube combater seus inimigos, conquistar novos territórios, acalentar seus subordinados. Entretanto, entre os poucos erros que cometeu, um foi o maior causador de sua ruína política: não impediu a eleição do papa Júlio II, o inimigo mais voraz de seu pai.

Todavia, consoante à relação entre virtú e fortuna, é importante salientar que, para Maquiavel, embora a fortuna, o acaso, proporcione chaves para o sucesso da ação política e possa constituir a parte da vida que independe da vontade do indivíduo, ele não compactua com a atitude passiva de fatalismos. Logo, o príncipe deve ser guiado pela prudência e, se possível, aproveitar-se da sorte. Assim, observa Maquiavel:

[...] quando um príncipe se apóia apenas na fortuna, arruína-se de acordo com as variações daquela. Julgo feliz, também, o que harmoniza sua maneira de agir com as características de cada época, e infeliz aquele cujo modo de proceder discorda dos tempos (MAQUIAVEL, 1998, p. 144).

[...] mudando-se a sorte, e conservando os homens, obstinadamente, o seu modo de proceder, são felizes enquanto esse modo de proceder e as características da época estiverem de acordo. [...] é melhor ser impetuoso do que prudente, $[\ldots]$ a fortuna como mulher, é sempre amiga dos jovens, pois são menos circunspectos, mais impetuosos e com maior audácia a dominam (MAQUIAVEL, 1998, p. 146).

As circunstâncias e a adaptação às circunstâncias são, porém, definidoras para o governante, por isso a flexibilidade é a chave do sucesso. De acordo com Ames (2002), para Maquiavel existiriam leis gerais, como "[...] a natureza das coisas e do homem comportam constantes que produzem necessariamente o retorno dos mesmos efeitos que, sendo adequados ou inadequados, exigem necessariamente meios análogos para os assumir ou evitar" (AMES, 2002, p. 84). Os fatos políticos não ocorrem de forma aleatória, obedecem condições de surgimento identificáveis. Interpretações fatalistas dos acontecimentos paralisam a ação, que por conseguinte provocam uma autoanulação da subjetividade prática. Para responder de forma eficaz às agruras da realidade diversa, contraditória e conflitual, requer-se do homem de poder ações novas e distintas diante 
das especificidades do momento. A ação política está condicionada pelo resultado, pela necessidade de obter certo fim, há uma lógica da ação. Os legisladores das repúblicas ou dos reinos, de acordo com Maquiavel, devem refrear os apetites humanos, retirando toda a esperança da impunidade. É a coerção que faz os homens desejarem viver coletivamente.

$\mathrm{O}$ autor dá uma nova interpretação para virtú e fortuna. Não aceita a posição de inércia, impotência e resignação diante da fortuna. É necessário, sempre, agir racionalmente, reconhecer e controlar situações políticas práticas. A influência da fortuna é proporcional ao seu conhecimento prático dos homens e da história, somados à sua capacidade de análise das situações e avaliação das consequências da ação. $O$ homem comedido, dotado de prudência e habituado a esse exercício terá possibilidades de encontrar a justa medida em seus atos. "Desse modo, o príncipe não deve ser crédulo nem precipitado, nem atemorizar-se, e sim proceder com equilíbrio, prudência e humanidade, para que o excesso de confiança não o torne incauto, nem a desconfiança excessiva o faça intolerável” (MAQUIAVEL, 1998, p. 106). Nesse excerto, o autor recomenda astúcia e prudência ao Príncipe, pois ele deve estar de prontidão diante dos momentos adversos. A justa via na ação política implica a alternância do uso do vício e da virtude. Desse modo, a interação entre virtú e fortuna tudo decide. Sendo a primeira a energia, o empenho, a vontade dirigida para um objetivo e a segunda, o acaso, a oportunidade, juntas vão tecer a rede em que se desenvolve o desejo do Estado unificado.

Enfatizamos, até então, o papel da fortuna e a importância do conhecimento da história, agora, de acordo com O Príncipe, destacaremos como deve ser o comportamento dos governantes diante das adversidades, para manter o poder e o controle no seu Estado. De acordo com Skinner (1996), por várias vezes Maquiavel sustentou que o principal dever do Príncipe era proteger sua própria segurança e força, para tanto, a virtú do governante é a chave para que ele mantenha seu estado. No entanto, aos seus súditos deve assegurar a estabilidade, a segurança e a liberdade, criando ordenações e leis que contemplem tanto o poder do príncipe quanto a segurança de todos, pois o "[...] povo não quer ser governado nem oprimido pelos poderosos, [...]” (MAQUIAVEL, 1998, p. 73). Para desviar o desprezo e o ódio e conservar o vulgo satisfeito é necessário: 
[...] não ser rapace e usurpador dos bens e das mulheres dos súditos. [...] Desprezível torna-se o príncipe considerado volúvel, leviano, efeminado, covarde, indeciso. [...] Deve ele fazer com que de seus súditos se reconheça a grandeza, a coragem, a gravidade e a fortaleza; [...] deve tornar irrevogável a sua sentença, comportando-se de maneira a que ninguém cogite enganá-lo ou fazer com que mude de idéia (MAQUIAVEL, 1998, p. 113).

Conclui-se, então, que um príncipe prudente deve pensar nos modos de ser necessário aos súditos, sempre, e de estes necessitarem do estado; depois, serlhe-ão sempre leais (MAQUIAVEL, 1998, p. 76).

Para Maquiavel, um dos aspectos que assegura a conservação do Estado está relacionado ao fato de o príncipe não ser alvo do ódio do povo. Nos Discursos sobre a primeira década de Tito Livio, ele declarou: "[...] os povos, como diz Túlio, mesmo sendo ignorantes, são capazes de entender a verdade e facilmente cedem, quando a verdade lhes é dita por homem digno de fé" (MAQUIAVEL, 2007, p. 23). A crise que se abatia sobre sua pátria exigia clareza, objetividade, determinação e sabedoria de todos.

Destacamos aqui que, para o autor, há "[...] em toda república dois humores diferentes: o do povo e dos grandes, e que todas as leis que se fazem em favor da liberdade nascem da desunião entre deles" (MAQUIAVEL, 2007, p. 22). Entre as distintas constituições de poder, a congruência é que em todos os casos o governo se divide entre o povo e os nobres e as leis resultam do conflito entre ambos. O Príncipe seria o representante de um dos lados em luta, o qual deveria assegurar o desejo do povo de não-opressão. Esse desejo faz do povo um aliado perfeito para o agente de poder. Nessas condições, a formação do Príncipe é fundamental, por isso, era premente ao Príncipe aprimorar sua educação, para, assim, ser possível o desenvolvimento do ideal da grandeza humana. Assim, recomendava Maquiavel:

Agora, no que diz respeito ao exercício do pensamento, deve o príncipe ler histórias de países e avaliar as ações dos grandes homens, verificar como se conduziram nas guerras, analisar os porquês de suas vitórias e derrotas [...] Um príncipe sábio deve prestar atenção a essas coisas e jamais permanecer ocioso nos tempos de paz; ao contrário, deve, com astúcia, ir juntando cabedal de que se possa servir nas adversidades, para sempre estar pronto a oporlhes resistência (MAQUIAVEL, 1998, p. 97).

Diante disso, podemos assinalar que, para Maquiavel, quanto mais acesso ao mundo da cultura o Príncipe tivesse, mais sábio ele se faria, 
mais teria condições de desenvolver e de aprimorar sua humanidade. $\mathrm{O}$ momento exigia do Príncipe sentimentos, conhecimento e sensibilidade que o auxiliassem a pensar e agir diante de situações novas. Esses requisitos poderiam ser desenvolvidos pela capacidade reflexiva dos homens, ou seja, pela autonomia intelectual. Essa formação, por sua vez, poderia ser refletida em toda a sociedade, pois, dependendo da compreensão que o Príncipe teria de educação, como modelo, os homens que ele dirige seriam formados e educados, ou não.

Maquiavel considerava necessário educar o povo no sentido de convencê-lo de que poderia existir apenas uma política, a realista, para alcançar o objetivo desejado e, portanto, seria preciso unir-se e obedecer àquele príncipe que empregasse esses métodos para alcançar o objetivo, pois só quem almeja um fim procura os meios adequados para alcançá-lo. Para tanto, o Príncipe deveria conquistar a confiança do povo, pois somente quando este, como um todo, responde pelo governo é que o bem comum é considerado de forma efetiva. Nesses termos, necessitava-se buscar ações que visassem à concretização do bem comum.

Em continuidade ao pensamento de como devem ser as ações do príncipe, segundo os conselhos de Maquiavel, adentramos em um ponto muito polêmico de sua teoria política: a ética. Indo na contramão de seus predecessores, Maquiavel sustenta que nem sempre podemos agir como gostaríamos no campo da política. A política real se ordena de maneira peculiar. Segundo Moraes (1981), Maquiavel declara que todos os atos ou procedimentos necessários à defesa do Estado ou ao bem da Pátria, úteis à comunidade ou ao príncipe que a encarna, serão morais. Ao contrário, os atos que objetivam a satisfação de interesses próprios e egoísticos são imorais. Para Maquiavel, a corrupção incapacita as pessoas de se dedicarem ao bem comum, levando-as a colocar em evidência seus próprios interesses em detrimento aos da comunidade.

Todavia, esse pensador argumenta que, em certas circunstâncias, são necessárias atitudes contrárias às virtudes cristãs (a Fé, a Caridade e a Esperança) e morais (a Prudência, a Temperança, a Fortaleza e a Justiça) recomendadas na literatura dos espelhos de príncipe.

Paradoxalmente, esse filósofo, indica, seguidas vezes, que é louvável o príncipe praticar as virtudes. No entanto, se ele não puder ser virtuoso, já que lida com homens perversos, deverá manter as aparências, para, com prudência, escapar da má reputação. Reportemo-nos às suas palavras: 
No entanto, não é preciso que o príncipe tenha todas as qualidades mencionadas; basta que aparente possuí-las. [...] um príncipe, em especial quando novo, não pode observar todas as coisas a que são obrigados os homens tidos como bons, pois é muitas vezes forçado, para manter o governo, a agir contra a caridade, a fé, a humanidade, a religião. [...] Deve o príncipe, contudo, cuidar para não deixar escapar dos lábios expressões que não revelem as cinco qualidades [...] devendo aparentar, à vista e ao ouvido, ser todo piedade, fé, integridade, humanidade, religião. [...] Procure, pois, um príncipe vencer e preservar o Estado. Os meios empregados sempre serão considerados honrosos e louvados por todos, porque o vulgo se deixa conduzir por aparências e por aquilo que resulta dos fatos consumados, [...] (MAQUIAVEL, 1998, p. 110-111).

Após analisar as relações da ética com a política, observando o abismo entre o modo como se vive e como se deveria viver, Maquiavel afirmou que ao príncipe não convém desviar-se do que é bom, se assim for possível. Todavia, quando for necessário, ele deve praticar o mal com sabedoria. Muitas vezes uma atitude franca e varonil, como um legítimo vir virtutis, revelava-se inadequada. Assim, no c. XVIII de O Principe, o secretário florentino aconselha o Príncipe a agir meio como animal e meio como homem para sobreviver em um contexto de corrupção. Ao definir o que seria uma boa finalidade, ele expressava sua visão da política e da humanidade. Ele via a humanidade de uma perspectiva muito pessimista: o homem era depravado, ingrato, egoísta. Prevenia o príncipe de que deveria ficar preparado para agir contra as convenções da fé, caso almejasse manter-se seguro. Deveria, também, afastar-se das veredas indicadas pela tradição sem medo e sem arrependimentos.

Maquiavel empreendeu uma revolução no gênero dos manuais de aconselhamento aos príncipes. Ele redefiniu o conceito de virtú. O Príncipe virtuoso não deve hesitar diante das necessidades, seja uma ação má ou virtuosa, para alcançar seus fins mais altos. A virtú passa a ter uma nova significação, ou seja, a qualidade de flexibilidade moral, indispensável para o Príncipe perceber e reconhecer o que se deve alterar em sua conduta quando os ventos da Fortuna assopram somadas as variações circunstanciais (SKINNER, 2010).

Em consonância com as formulações tecidas, podemos concluir que o legislador pode ser interpretado sob a perspectiva do conjunto de crenças, sentimentos, interesses e argumentos do seu período histórico e de sua essência humana. Como pondera Ames (2002, p. 52), para 
[...] Maquiavel, o homem se realiza na terra e, conseqüentemente, os fins que persegue devem também ser terrenos. Este é o ponto de partida de suas reflexões sobre as forças que atuam no homem, as suas reações primigênias, as tendências de sua vontade e de sua razão. Tudo o que resulta desse jogo entrecruzado de tendências (dos indivíduos entre si, dentro de uma comunidade e das comunidades entre si como organismos) torna-se valioso, porque isso e não outra coisa constitui a vida humana.

Essa máxima liberta a ação do agente de poder da limitação imposto pela moral existente até então. O legislador não pode ser visto como indivíduo, mas como reflexo de determinada vontade coletiva. Não se pode julgar um homem político de acordo com sua maior ou menor honestidade, por agir ou não com equidade, mas por cumprir ou não seus compromissos, o juízo deve ser político e não moral.

Para concluir nossa análise da obra do autor florentino, refletiremos sobre quais seriam os fundamentos do governo, independentemente do modelo de Estado.

Para Maquiavel os alicerces do governo seriam boas leis e boas armas. Possuir um exército próprio seria de suma importância para a segurança do Estado, por isso o príncipe deveria dominar a arte da guerra, possuir destreza, pois existindo boas armas, existiriam boas leis. Como era de sua opinião que a corrupção se alastrava pela Península Itálica, era de vital importância que o Príncipe se mantivesse firmemente no poder. Essa situação corrompida e humilhante da Itália exigia instrumentos radicais para curá-la. A insegurança política da Itália justificava sua obstinação pela estabilidade política, a qual deveria ser conquistada pela astúcia e pela força. Por isso, em O Príncipe, enaltece a ação dos profetas armados, sendo “[...] os maiores Moisés, Ciro, Rômulo, Teseu [...]” (MAQUIAVEL, 1979, p. 54). Estes, segundo o florentino, foram fundadores de reinos dignos de admiração. Desse modo, Maquiavel concede acentuada relevância ao fim que a força bruta cumpre na vida política.

E os principais fundamentos dos Estados, sejam eles novos, velhos ou mistos, são boas leis e boas armas. [...] As mercenárias e as auxiliares são inúteis e perigosas. Se alguém mantiver seu Estado apoiado nessa classe de forças, nunca haverá de estar seguro; [...] O Estado é espoliado por elas na paz; na guerra, pelos inimigos [...] (MAQUIAVEL, 1998, p. 85-86).

Em suma, nas tropas mercenárias é perigosa a covardia; nas auxiliares, o mérito. [...] Carlos VII, pai do rei Luís XI, que com sua boa fortuna e mérito libertou a França do jugo inglês, apercebeu-se da necessidade de se armar com 
tropas próprias e assim tornou obrigatório, no reino, o serviço militar (MAQUIAVEL, 1998, p. 92-93).

[...] Um príncipe não deve ter outro objetivo ou pensamento, ou manter qualquer outra coisa como prática, a não ser a guerra, seu regulamento e sua disciplina, pois essa é a única arte que se espera de quem comanda. [...] A causa que te levará a perder o domínio, em primeiro, é descuidar dessa arte, e só o poderás conquistá-lo ao professá-la. [...] deve se preocupar sempre com a arte de guerra, e praticá-la na paz mais ainda do que na guerra, [...] (MAQUIAVEL, 1998, p. 95-96).

Para Maquiavel, o amor à pátria, o uso da violência pela sua causa, constituía-se como elemento necessário à virtús do legítimo cidadão. Esse estadista conclui declarando a importância de um Príncipe ter uma milícia constituída por cidadãos, pois, caso contrário, estaria à mercê da fortuna. Destaca que isso é necessário porque em momentos difíceis não haverá virtú que mantenha o Estado seguro.

Constatamos, pois, que a relação do pensamento de Maquiavel com o Absolutismo expressou-se em diversos sentidos. Em sua obra $O$ Príncipe, ele se pôs no limiar da teoria política moderna, usando o termo Estado em sentido novo. Ao afastar do Estado os imperativos da moral corrente, o autor tornou-se o arauto da autonomia da política, afirma Chevallier (1957). Espelhando-se no modelo de Estado nacional monárquico francês, em sua visão, o Estado moderno já se mostrava na própria linguagem. Para ele, o Príncipe deveria romper todas as concessões perigosas, concentrar-se no poder e exercê-lo com rigor, pois o Estado se revela como obra do homem. Ele pressentiu que o destino das nações europeias era de se consolidar como monarquias soberanas que deveriam se governar com o consenso dos súditos. A monarquia absoluta seria limitadora do poder dos papas, fundadora de grandes Estados territoriais nacionais, função que não poderia se realizar sem o apoio da burguesia e de um exército permanente, nacional, centralizado, entre outros. Assim, do legado de Maquiavel, o que ficou foi um padrão de pensamento que se tornaria postumamente conhecido como razão de Estado.

Percebemos, enfim, que os escritos de Maquiavel iam ao encontro das questões postas em seu momento, fazendo parte do cabedal das ideias legitimadoras do poder régio, as quais ganhavam força e aceitação na sociedade. A obra O Príncipe era privada, destinava-se aos príncipes e, em especial, ao novo príncipe de Florença, da família Medici. No entanto, sem ignorar os valores humanos, inclusive os morais e religiosos que 
norteavam a formação do sujeito, seu manual expressava um modelo de educação para toda a sociedade. Os homens têm responsabilidade para com os demais homens e a educação assume função primordial. Desse modo, todo o ensino e todo o aprendizado pressupõem ações éticas.

Sublinhamos, pois, que o pensamento político de Maquiavel se construiu conforme sua visão do contexto geral da Europa, sem o qual seu pensamento seria utópico. Ele superou a experiência italiana com o exemplo das nascentes nações europeias. Em um período de luta e consolidação de um novo poder, exigia-se, segundo ele, a arte de mediar. As formulações de Maquiavel contribuíram para a formação dos princípios dos Estados absolutos, pois entendia que somente um governante com poder absoluto seria capaz de resolver os problemas da época. Segundo Chevallier (1957), após a primeira impressão do O Príncipe, em 1531, com autorização do Papa Clemente VI, as edições dessa obra multiplicaram-se, especialmente a partir de 1550. O Príncipe se tornou o livro de cabeceira dos soberanos absolutistas.

Com base nas ideias construídas ao longo do texto, podemos afirmar que a formação do Estado Absolutista permitiu que os homens, agindo de forma coletiva ou singular, se organizassem e definissem objetivos comuns para o desenvolvimento do indivíduo e da sociedade. A história exemplifica que a cooperação entre os homens, visando a um bem coletivo, foi responsável pelas realizações humanas e que esse é o papel da Educação. Ao formar o homem de forma integral (cognitiva, sensível e eticamente), a educação lhe oferece a possibilidade de compreender, estabelecer os limites e definir as ações necessárias para a convivência. Independentemente do tempo e dos limites espaciais, a educação se faz presente em qualquer organização social, uma vez que os homens se influenciam, mutuamente, por meio de suas relações cotidianas, aprendem uns com os outros.

Maquiavel começou sua carreira numa posição de poder e prestígio e morreu pobre e em desgraça. Todavia, mediante uma combinação de gênio e talento como escritor, essa derrota tornou-se o fundamento para obras de sucesso duradouro. A desgraça, que o afastou de sua posição de alto funcionário do Estado, levou-o a dedicar tempo e esforço para escrever suas principais obras, resultante de uma profunda reflexão sobre a atividade política. Foi, portanto, a desgraça na política que possibilitou sua grandeza como historiador da política. 


\section{Considerações finais}

Observamos que a obra desse florentino exprimiu, pela primeira vez, a noção de Estado como forma de organização da sociedade da maneira como a concebemos hoje. É notável constatar que as análises de Maquiavel referentes à política de seu tempo conservam-se atuais. Percebe-se hoje, nas relações entre os estados e na própria sociedade, a competição, o jogo de interesses particulares. Nota-se a falta do engajamento das pessoas em projetos coletivos e em causas mais amplas.

A grandeza de sua obra continua a nos atrair, sendo uma inesgotável fonte de sabedoria política importante para o melhor entendimento das questões que permeiam os debates políticos de nossa época. Ao lermos os clássicos percebemos o quanto eles se conservam atuais. Eles permanecem porque tratam questões humanas para além do tempo vivido por eles. Os autores que se tornaram clássicos tiveram consciência das questões de sua época, se posicionaram e se esmiuçaram nos problemas sociais. Maquiavel se envolveu com os problemas do seu tempo e, com determinação, buscou meio de resolvê-los.

Sublinhamos que aprendemos melhor o contexto da nossa própria vida quando aprofundamos a vida de homens que pertenceram a outras sociedades. Assim, a obra de Maquiavel nos serve como modelo para termos uma vida ativa, nos colocando como agentes partícipes dos problemas de nossa época, buscando soluções, para que os homens e a sociedade se desenvolvam, possibilitando o bem viver. É certo que cada um de nós almeja viver em paz e usufruir as vantagens de um mundo sem conflitos. Todavia, a simples vontade de extirpar os conflitos não será suficiente, é necessário, pois, por meio da ação, construir instituições que acolham, transformam e materializam os desejos diversos dos homens, que permitam a convivência coletiva. A sociedade deve ser composta de indivíduos ligados por laços de responsabilidade, de comprometimento, seja em relação uns com os outros seja em relação à realidade, cuja destruição leve à perda dos indivíduos.

Reconhecer as atuais circunstâncias históricas, mediante uma análise acurada e realista do mundo, não deve nos entregar à impotência, à inércia e à passividade, mas deve nos levar a desejá-lo melhor e, acima de tudo, agir, pois é por meio da ação que os homens realizam suas obras em comum. Verifica-se, assim, a necessidade da formação de sujeitos 
conscientes, que atuem nas suas respectivas ambiências cotidianas. Esse é, pois, o legado de Maquiavel. O seu projeto social era, juntamente com outros do seu tempo, reencontrar o vigor perene que acreditava ter existido nos primeiros tempos da República e restituir a Florença e à sua Itália o esplendor de um regime que agonizava.

Concluímos, portanto, que a obra de Maquiavel é importante para o contexto das análises concernentes à Educação do século XXI, pois nos permite compreender os fundamentos da formação política da sociedade moderna e, por conseguinte, compreender a formação do homem político moderno.

A ética, a moral, as virtudes e o conhecimento são os elementos essenciais para a formação do governante e este ser humano devia ser construído por meio da observação e do ensino. Esses princípios perenes, resistentes às vicissitudes dos tempos, constituem-se como base para fazer renascer a saúde do tecido social. Entendemos a composição de Maquiavel como extremamente relevante àquela sociedade, pois a importância da vida material implicava uma postura educacional que valorizava o ensino da ética, voltado para uma melhor organização da vida social, que favorecesse um viver mais solidário e harmonioso entre os homens.

Consideramos, pois, que o conhecimento que os homens construíram é que tornou possível a convivência entre eles, ou seja, com base na educação, eles formaram a sociedade em que viviam: suas instituições, crenças, filosofia, arte e ciência.

\section{Referências}

AMES, José Luiz. Maquiavel: a lógica da ação política. Cascavel: Edunioeste, 2002.

BATH, Sérgio. Traduzindo Maquiavel. In: Maquiavel: um seminário na Universidade de Brasília. Brasília: UnB, 1981. p. 9-14.

BIGNOTTO, Newton. Nicolau Maquiavel (1469-1527) e a nova reflexão política. In: MAINKA, Peter Johann Mainka. (Org.) A caminho do mundo moderno: concepções clássicas da filosofia política no século XVI e o seu contexto histórico. Maringá: Eduem, 2007. p. 49-71.

BIGNOTTO, Newton. Maquiavel republicano. São Paulo: Loyola, 1991. (Coleção Filosofia)

BLOCH, Marc Leopold Benjamin. Introdução à História. Lisboa: Publicações Europa- 
América, 1965.

BURKHARDT, Jacob. O renascimento italiano. Lisboa: Editorial Presença, Livraria Martins Fontes, 1973.

CALVINO, Italo. Porque ler clássicos? São Paulo: Companhia das Letras, 1993.

CHEVALIER, Jean-Jacques. As grandes obras políticas de Maquiavel a nossos dias. Rio de Janeiro: Livraria Agir, 1957.

DUBY, Georges. Ano 1000, ano 2000: na pista de nossos medos. São Paulo: Unesp, 1999.

GRAMSCI, Antonio. Maquiavel, a política e o Estado moderno. 8. ed. Rio de Janeiro: Civilização Brasileira, 1991.

HALE, John R. Maquiavel e a Itália da Renascença. Rio de Janeiro: Zahar Editores, 1963.

MAQUIAVEL. O Príncipe - Curso de introdução à ciência política. Brasília: Editora Universidade de Brasília, 1979.

MAQUIAVEL. O Príncipe: Escritos Políticos. São Paulo: Nova Cultural, 1998. (Pensadores)

MAQUIAVEL. Discursos sobre a primeira década de Tito Livio. São Paulo: Martins fontes, 2007.

MASTERS, Roger Davis. Da Vinci \& Maquiavel: um sonho renascentista: de como o curso de um rio mudaria o destino de Florença. 1. ed. Rio de Janeiro: Jorge Zahar, 1999. MORAES, Lauro Escorel de. Maquiavel e o pensamento político. In: Maquiavel: um seminário na Universidade de Brasília. Brasília: UnB, 1981. p. 15-28.

SALDANHA, Nelson. O Estado moderno e a separação de poderes. São Paulo: Saraiva, 1987. SKINNER, Quentin. Maquiavel. Porto Alegre, RS: L\&PM, 2010.

SKINNER, Quentin. As fundações do pensamento político moderno. 1. ed. São Paulo: Companhia das Letras, 1996.

\section{Notas}

1 Segundo Bignotto (2007), com o apoio de Lodovico Sforza (1452-1508), príncipe de Milão, cidade politicamente rival de Florença, Carlos VIII (1470-1498), rei da França, invade a Itália, em 1494, dando início a uma série de invasões e guerras e deixando a Itália vulnerável às disputas de poder de soberanos europeus. Florença, sob a ameaça de saque e destruição, fez com que Piero (1471-1503), filho de Lourenzo (1449-1492), o Magnífico, intimidado, cedesse às demandas do invasor, provocando, assim, grande insatisfação do povo florentino, mediante sua covardia. Em meio a essa turbulência, o soberano é deposto depois de entregar Pisa aos franceses, deixando cair por terra os sessenta anos de domínio dos Medici (1434-1494).

2 Com o intuito de impedir os abusos dos Medici, foi organizado um Grande Conselho, formado por cidadãos cujos pais ou avós haviam sido elegíveis para cargos públicos. Esse Conselho indicava cargos destinados a um Conselho dos Oitenta. Dentre os funcionários que ocupavam cargos administrativos, neste segundo Conselho, estavam os chanceleres e secretários. Na prática, as eleições da república florentina eram dominadas por famílias ricas e poderosas, que formavam alianças com grupos privilegiados por meio do apadrinhamento e favores. A eleição de Maquiavel ao cargo influente de 
Segundo Chanceler se deu devido a essas alianças, baseadas na riqueza, família, confrarias (MASTERS, 1999).

3 De acordo com Masters (1999), em 11 de março de 1513, após a morte do papa Júlio II (1445-1513), o cardeal Giovanni de Medici, filho de Florença, torna-se o novo pontífice, assim, em meio ao regozijo dos florentinos, os prisioneiros são anistiados, ficando, então, livre Maquiavel.

4 Espelhos dos príncipes eram livros de aconselhamento destinados aos príncipes e outros magistrados para bem governarem. Essas obras enfatizavam as virtudes que deveria possuir um bom governante e indicavam que todas as suas ações deveriam estar em conformidade com as quatro virtudes cardeais: a prudência, a magnimidade, a temperança e a justiça. A temática dessas virtudes tornou-se característica principal dos moralistas renascentistas. Praticamente não analisam a estrutura administrativa, mas compartilham da importância da análise das atitudes que os revestidos de poder devem tomar, a fim de ter sempre o bem comum da cidade. Tendiam a minimizar a relevância do cidadão individualmente considerado, centrando sua atenção no personagem bem mais imponente e influente, o príncipe. Entre muitos outros escritores desse gênero textual, citamos Francesco Patrizi (1412-94), que endereçou sua obra Do reino e da educação do rei, escrita na década de 1470, ao papa Sisto; e o mais célebre deles é a obra O Príncipe, de Nicolau Maquiavel, redigida em 1513, destinada ao príncipe Lourenço de Medici IV, objeto deste estudo. No final do século XV, os escritos de aconselhamento e elogios ao monarca alcançaram o apogeu (SKINNER, 1996).

5 Masters (1999) informa-nos que, em uma carta a Lourenço, filho de Piero de Medici, Maquiavel declarou que estava escrevendo um manual de conselhos para os príncipes, especialmente para o novo príncipe de Florença, da família Medici, com o intuito de auxiliá-lo a manter o poder e o controle no seu Estado.

6 Maquiavel, em 1502-3, acompanhou César Bórgia em uma missão diplomática.

Recebido: $21 / 10 / 2010$

Aprovado: $18 / 08 / 2011$

Contato:

Universidade Estadual de Maringá Centro de Ciências Humanas Letras e Artes Departamento de Fundamentos da Educação Avenida Colombo, 5790 Jardim Universitário CEP $87020-900$ Maringá, PR Brasil 